\title{
FEATURE Sinkholes and sand boils during 2011 record flooding in Cairo, Illinois
}

Lois Wright Morton and Kenneth R. Olson

$\mathrm{T}$

he southwestern tip of Illinois is bounded by the Mississippi and Ohio rivers, which converge at Cairo (figure 1), a river city with a long history of steamboats, barges, railroads, and road bridges spanning three states. The physical, economic, and social reconstruction of this flood-prone peninsula following the evacuation of the entire city on May 1, 2011, challenged local residents, community leaders, and the US Army Corps of Engineers (USACE) to strengthen levees, repair roads and bridges, and strengthen other basic infrastructure. While the Cairo floodwall and levee system was able to withstand the recordbreaking flood of 2011 (NOAA 2012), it took more than two years for sand boils and sinkholes to be repaired. By the fall of 2013, the weakened levees and the floodwall were reengineered and strengthened in preparation for future flood events.

\section{THE OHIO AND MISSISSIPPI RIVERS}

Cairo has a history of battling two rivers that are its economic lifeblood and also its greatest source of unease and vulnerability. The approximately 4,000 ha $(10,000 \mathrm{ac})$ between the Ohio and Mississippi rivers where the city is located today were originally an 1818 land trust owned by land speculator investors from New York City and Philadelphia (Lansden 1910). The first levee system around Cairo was completed in 1843 to secure Cairo from the abrasions of the Ohio and Mississippi rivers and make riverfront and interior city lots desirable for purchase. Early engineers noted important differences between the Ohio and Mississippi rivers that had implications for construction of levees and offer explanations to Cairo's 2011 vulner-

Lois Wright Morton is professor of sociology in the College of Agriculture and Life Sciences, lowa State University, Ames, lowa, and Kenneth R. Olson is professor of soil science in the College of Agricultural, Consumer, and Environmental Sciences, University of Illinois, Urbana, Illinois. ability to flooding and levee crevassing. An 1807 government surveyor wrote the "Mississippi devours its banks and changes its current from place to place unless restrained..." and its rapid, whirling current is loaded with sand and silt (Lansden 1910). In contrast, the Ohio River had clearer water and slower movement with the origins of its waters from the forested lands of Pennsylvania, Indiana, and Ohio to the northeast, and from the Tennessee River to the south, the largest tributary coming out of Virginia, West Virginia, and Kentucky. After many years of farming in the Ohio River Valley, the sediment load has increased substantively, and the water is now a yellowish brown color, reflecting erosion of timber soils (Alfisols). Since the 1930s, an extensive federal bank stabilization and revetment program has reduced the land scouring and Mississippi River meandering threats to levees in the confluence area.

The Ohio River has historically posed the greatest danger (which continues today) to Cairo, as it "claims for itself the right to rise and fall through a perpendicular distance of fifty feet" (Lansden 1910). Lansden (1910) further reported that the Ohio was filled by early heavy spring rains from the east with 1882, 1883, and 1884 having the highest flood stages prior to 1910 . In the 1800 s, the Mississippi River and tributaries north of Cairo often froze over, and northern spring snowmelts brought high waters to the Ohio-Mississippi river convergence three to four months (from June 1 or later) after the Ohio peak high waters passed (Lansden 1910).

The historical levees-only strategy of the USACE resulted in construction of levees on both sides of the Lower Mississippi River from Cairo, Illinois, to New Orleans, Louisiana (Barry 1997; Camillo 2012), as a response to flood waters from both these rivers and their tributaries. Cairo, located on low-lying alluvial soils at the confluence of the Mississippi and Ohio rivers did not have a major flood problem until the federal and local agencies extended the levee systems in the vicinity (Camillo 2012). That levee construction, along with the sealing off of the natural diversion through the St. Francis River south and west of Cape Girardeau, Missouri, represented the origin of the flood problems at Cairo. In 1843, Cairo was the first city north of New Orleans to build a levee system. The levees-only strategy was modified with the creation of four separate floodways: one in Missouri (Birds Point-New Madrid Floodway) and three in Louisiana (West Atchafalaya Floodway, Bonnet Carre Spillway and Floodway, and Morganza Spillway and Floodway). The USACE decision to add floodways was a substantive shift in river management from confinement only to a dispersion approach intended to divert excess flows during large flood events (Camillo 2012). In the 1940s, Cairo benefited from the USACE building of the Kentucky Dam on the Tennessee River and in 1960s from the building of the Barkley Dam on the Cumberland River to better control the fast rise of the Ohio River during spring rains.

In 2009, Clyde Walton boasted in the foreword to Lansden's 1910 History of Cairo Illinois, "Today Cairo lives secure behind the mighty levees that protect it from ravage by the two great rivers." Little did he suspect that the Flood of 2011 would challenge the claim that "mighty levees" would protect Cairo. While the reservoirs along the Ohio River tributaries helped lower the 2011 Ohio River high water levels, in the end they were inadequate to prevent downstream flooding, and it became necessary to open the Birds Point-New Madrid Floodway to protect Cairo levees and floodwalls as well as downstream cities (Olson and Morton 2012a). The convergence of earlier than usual snowmelt in the Upper Mississippi River tributaries and heavy spring rainfall in eastern Ohio River tributaries produced flood levels in late April/early May of 2011 to rival 1927 and 1937 floods. The 
pressure of the swollen Ohio River threatened the Cairo floodwall and levee system and the community it protected (Camillo 2012; Olson and Morton 2012a, 2012b, 2013a, 2013b, 2014).

\section{SAND BOILS, MEGA SAND BOIL, AND SINKHOLES IN CAIRO}

As a record deluge surged toward the confluence of the Mississippi and Ohio rivers in the spring of 2011, officials had to initially decide how to protect the town of Cairo, Illinois, and whether to flood 54,824 ha (133,000 ac) of Missouri farmland and its small communities to lower river pressure on levees. Sand boils discovered on April 28, 2011, signaled the levee and floodwall were at risk and could fail. Cairo was evacuated on May 1, 2011, after more sand boils and sinkholes appeared inside the floodwall (see figure 1). Commerce Street, built on "made land" (Parks and Fehrenbacher 1968), had a number of sinkholes open up (figure 2) where a sanitary sewer line flowed to the sewage treatment plant and parallel to the floodwall. Soils mapped as "made land" (Parks and Fehrenbacher 1968) are essentially soil materials high in clay, silt, or sand that were hauled in as fill materials to build up the low bottomlands of Cairo.

Sand boils, including a mega sand boil, occurred near the water treatment plant on 40th Street, revealing a weakening levee and floodwall system. The soil at the site of the mega sand boil was Darwin silty clay loam (Parks and Fehrenbacher 1968), which contains more than $40 \%$ clay in the upper $2 \mathrm{~m}(6.6 \mathrm{ft})$. Combined with the heavy local rains on May 1 and 2, the Cairo gage forecast was pushed to a peak of 19.4 $\mathrm{m}(63.5 \mathrm{ft})$ and placed additional pressure on these structures (Camillo 2012). These events were finally enough to convince the president of the Mississippi River Commission (MRC), Major General Michael Walsh (USACE), that the Birds Point-New Madrid Floodway had to be opened for the first time in 74 years.

When the rivers are at high water, Cairo is like an empty basin sunk to its brim and even a tiny opening at the bottom can force a stream of water to shoot up through the porous earth or sand inside the basin (Lansden 1910). In late April, small

\section{Figure 1}

Map of Cairo, Illinois, and the confluence of the Ohio and Mississippi rivers. Map created by Mic Greenberg.

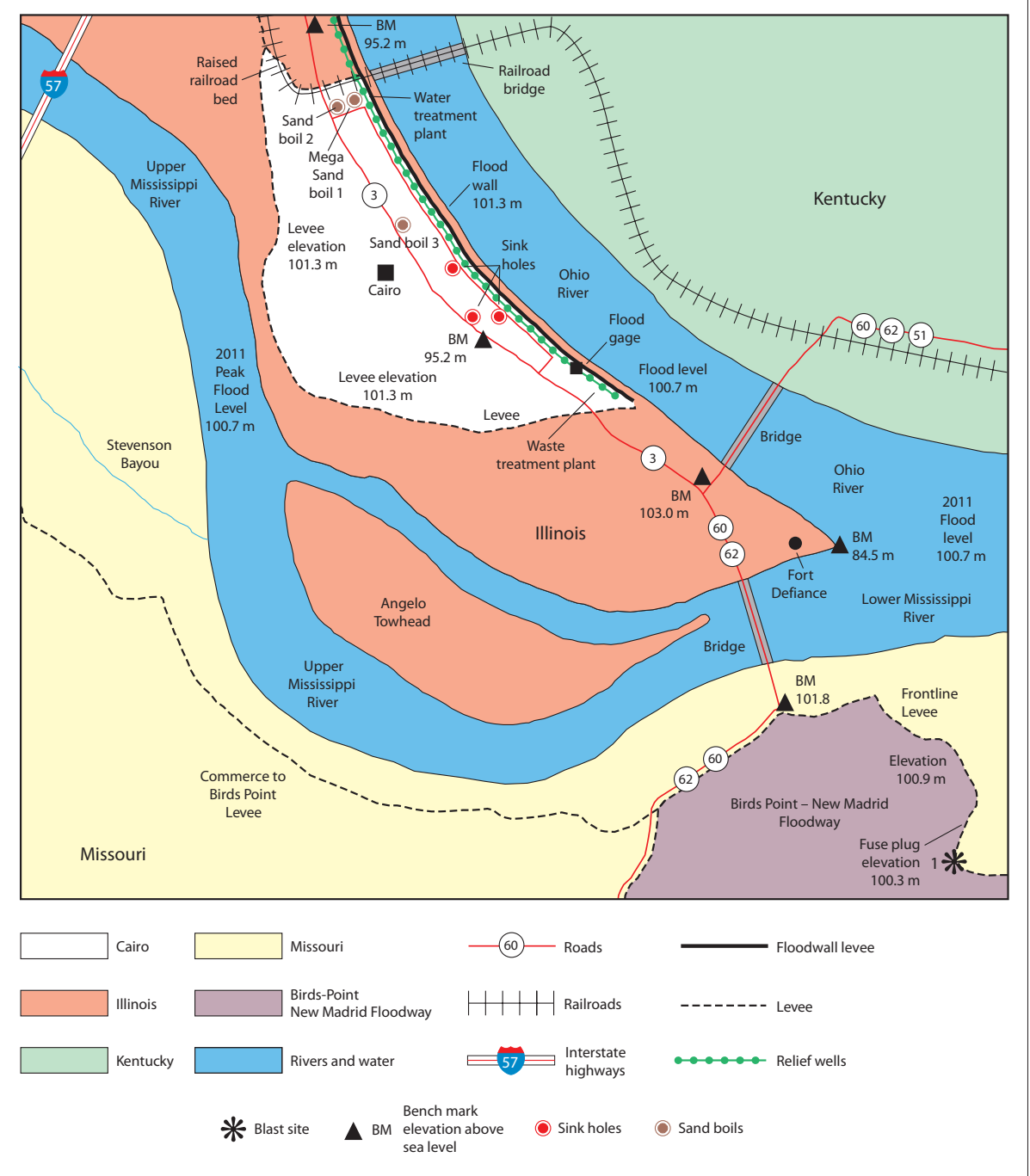

sand boils began appearing in Cairo. The first mega sand boil of the 2011 flood was found (Camillo 2012) by USACE beside a piezometer (a gauge which measures pressure of the groundwater) near 40th Street just south of the raised railroad bed and west of the water treatment plant (figure 1). A sand boil (figure 3) occurs when extreme water pressure against a levee leads to high hydraulic gradient conditions resulting in excessive seepage and piping of sediment exiting on the inside ground surface in a churning or boiling action (Veesaert 1990). Uncontrolled seepage is a major cause of levee failure, creating instability when high water pressure and saturation causes the earth materials to lose strength. A certain amount of under- seepage is an expected occurrence and not a major problem as it is incorporated into levee designs. Without some underseepage, the pressure on the levees would be too great; however, piping of sediment in the underseepage is a real problem (Camillo 2012). A sand bag dike is often used as a temporary measure to increase the depth of water over the boil and decrease the hydraulic gradient across the seepage path, thereby reducing the potential for erosion of earth materials along the path, a process called piping (Veesaert 1990). If a boil is piping sediment, the USACE becomes quite concerned and starts ringing the boil with sandbags to apply a counter pressure through the rings or water berms. The engineers are careful not to put too much 


\section{Figure 2}

The Commerce Street sinkholes that are near or above the sanitary sewer lines.

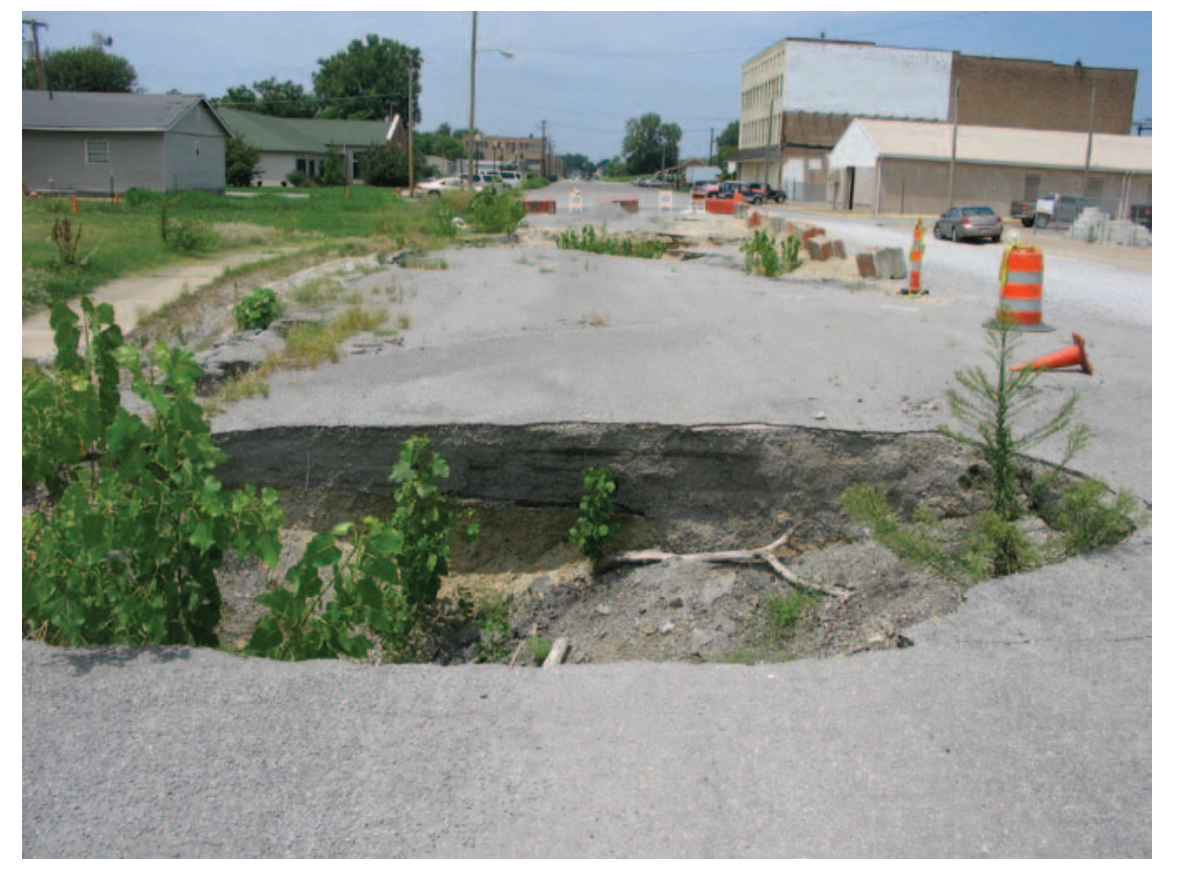

\section{Figure 3}

Diagram of sand boil at Cairo on April 28, 2011. The elevation of the highest flood level (101.2 m) of May 2, 2011, and the low drought level of August 25, 2012, are noted on Cairo gage. Diagram created by Mic Greenberg.

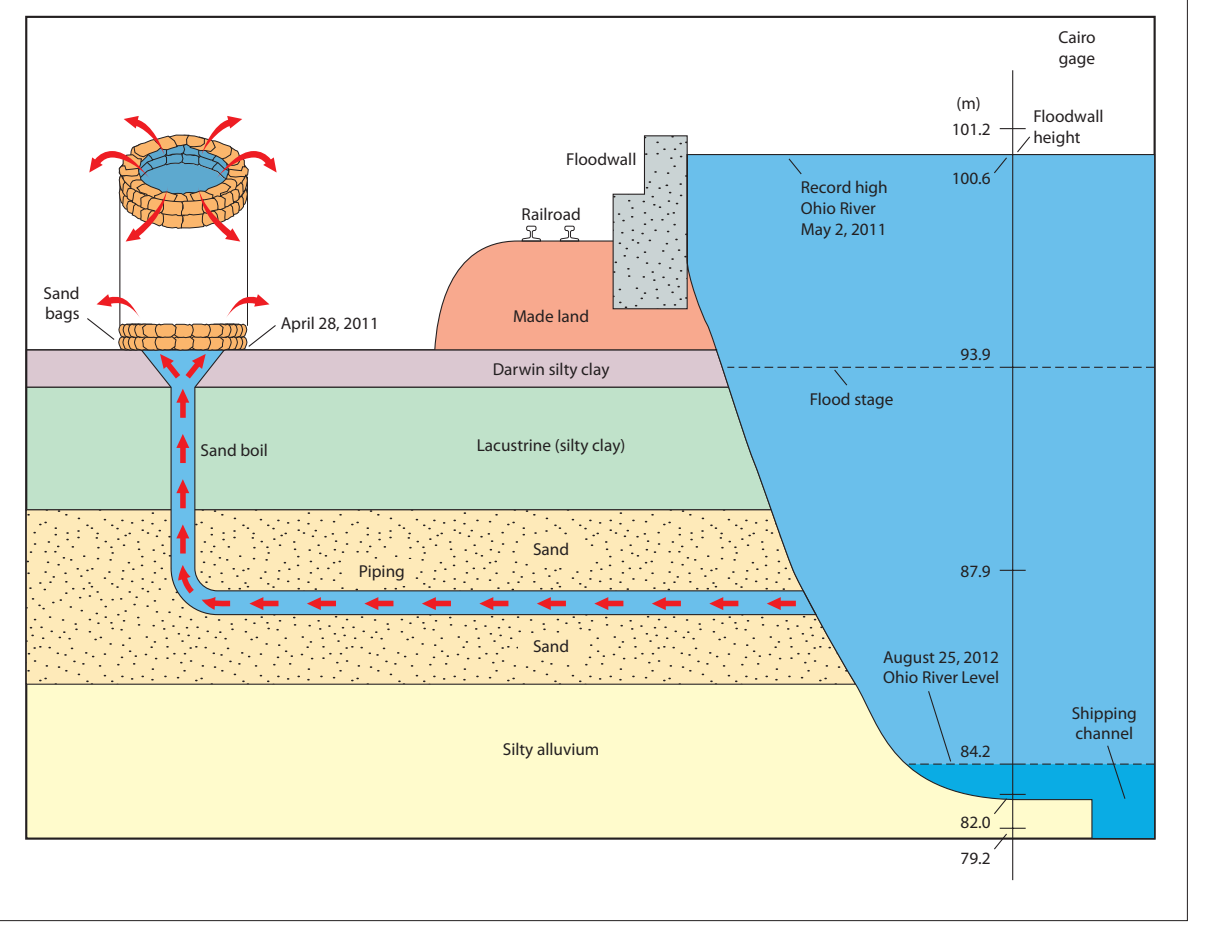

pressure on the boil or it could serve to completely stop the underseepage or flow of water. Piping is what undermines the levees or floodwalls (Camillo 2012).

The sand boil occurred on Darwin silty clay loam soil (Parks and Fehrenbacher 1968), and on the evening of April 28, 2011, this high energy sand boil (figure 3) started to grow. In a few hours it enlarged dramatically from a few centimeters (few inches) to $0.6 \mathrm{~m}(2 \mathrm{ft})$ in diameter. The USACE quickly realized that this high energy sand boil had the potential to cause the Ohio River floodwall to fail at a time when 2,900 people were still in Cairo. The USACE decided that the traditional treatment of building a sand bag ring around the sand boil to keep water on the boil as a counter weight was insufficient and would not work this time. Instead they constructed a ring berm around the sand boil using a nearby stockpile of fly ash cinders (figure 4) owned by the Bunge Corporation (Camillo 2012). A bank of emergency lights were brought in as well as a bulldozer, backhoes, loader, excavators, dump trucks, and a crew of 40 to contain the large sand boil. The crew constructed a $15 \mathrm{~m}$ (50 ft) ring berm to a height of 2 $\mathrm{m}(6.6 \mathrm{ft})$. The sand boil continued to pipe sediment at an alarming rate. Since the city of Cairo still had many people who were not yet evacuated, the danger of the city being flooded with loss of life was a real concern. On May 2, 2011, after 48 hours of local rain, the fly ash cinders pile was turning to mush and had to be covered with a tarp (Camillo 2012). The fly ash cinder pile was then raised to $4 \mathrm{~m}(13.2 \mathrm{ft})$ (figure 4) to finally control the boil. This mega boil was among the most serious in the history of USACE use of earthen levees and floodwalls.

Previously, on April 29, 2011, another smaller sand boil was also found near the NAPA store to the east of Route 3, which was between 40th Street and the raised railroad bed (figure 1). This sand boil occurred on Cairo silty clay soil (Parks and Fehrenbacher 1968) and was treated with the traditional $1.5 \mathrm{~m}(5 \mathrm{ft})$ high sand bag ring. The Illinois National Guardsmen filled the sand bags in the parking lot of the NAPA store and then moved them through $0.6 \mathrm{~m}(2 \mathrm{ft})$ of water 


\section{Figure 4}

The 40th Street mega sand boil in Cairo near the water treatment plant and the raised railroad bed. The mega sand boil was filled in and covered with a $4 \mathrm{~m}$ high pile of fly ash cinders.

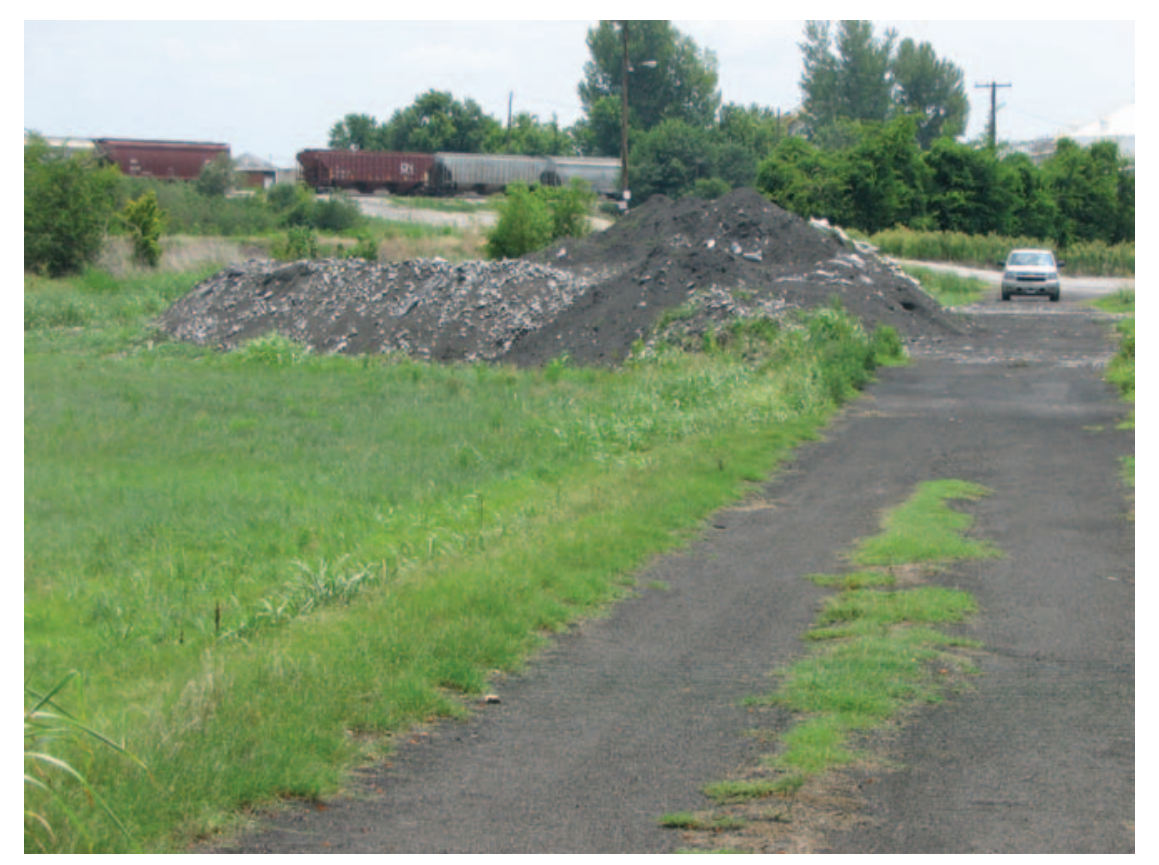

to the sand boil using flat bottom boats (Camillo 2012). Later an access road had to be built so the National Guard could haul in rock to reinforce the sand bag ring. This effort finally stabilized the second sand boil. A third sand boil on Tice silty clay loam soils (Parks and Fehrenbacher 1968) was later discovered off of 27th Street approximately $150 \mathrm{~m}(500 \mathrm{ft})$ from the Ohio River floodwall (figure 1). It was smaller than the other two sand boils and was treated with a $1.3 \mathrm{~m}(4 \mathrm{ft})$ high ring of sand bags and filled with water.

A number of sinkholes also developed in late April and early May of 2011 in downtown Cairo on Commerce Street and 15th Street (figure 2). A sinkhole is a hole in the ground surface created by the collapse of overlying material as supporting material below the surface is eroded or piped by water (Veesaert 1990). Sinkholes have steep sides from the soil shearing as it collapses into the underlying void (Veesaert 1990).

The Cairo sand boils, mega boil, and sinkholes represent uncontrolled seepage conduits that formed under the levee system and threatened the city. Following the 2011 flood event, Cairo and USACE invested considerable resources to repair the sand boils and to reduce future risk of uncontrolled seepage underneath the floodwall, which undermines the levee system (figures 3 and 5). Repairing such boils can be complicated, with the possible approaches including relief wells, seepage berms, and cutoff walls, which involve digging a big trench and adding clay grout to cut off the leak (Koenig 2012). In October of 2012, the USACE began obtaining the rights to install 31 relief wells adjacent to the Cairo floodwall (figure 1) with construction completed by the fall of 2013 .

\section{IMPACTS OF FLOODING ON URBAN STRUCTURES AND AGRICULTURAL CROPS AND SOILS}

The Cairo levee is set back 0.5 to $2 \mathrm{~km}$ (0.3 to $1.3 \mathrm{mi}$ ) from the upper Mississippi River leaving the agricultural bottomland outside the levee unprotected from flooding. Cropland areas not protected by levees can store significant amounts of floodwater during the nongrowing season with minimal damage to soils and crops that have not yet been planted. About 200 ha $(500 \mathrm{ac})$ of Illinois farmland composed of Tice silty loam and Gorham silty clay loam soils (Parks and Fehrenbacher 1968) is located northwest of the Fort Defiance Park and between the Upper Mississippi River and the Cairo levee (figure 1). This farmland was under water for the entire months of April and May in 2011. After both the Ohio and Upper Mississippi rivers dropped and drained in early June of 2011, these fields were planted to soybean (Glycine max L.; figure 6). June is the normal planting time for soybean, so very little yield loss occurred. An additional 80 ha $(200 \mathrm{ac})$ of alluvial land is mapped on the east side of the Upper Mississippi River (figure 1) and south of I-57. Only 10 ha (25 ac) are cultivated, and the other 70 ha $(175 \mathrm{ac})$ remain in forest. All of the agricultural land was planted and harvested in 2011. No crop insurance benefits were paid to farmers in the area for flooding damage to the crop since there were no significant crop losses or yield reductions.

There were no visible signs of soil erosion or soil damage in these unleveed agricultural lands after the floodwaters receded in early June of 2011. Failed levees are the most common cause of significant soil erosion and soil damages in the form of crater lakes, gullies, and sand deltas (Olson and Morton 2012b, 2013b) along the Ohio and Mississippi rivers. During April of 2011, the slow rise in Ohio and Mississippi rivers covered unleveed farmland with floodwater that eventually reached depths of more than $6.7 \mathrm{~m}(22 \mathrm{ft})$. The floodwater left behind a thin silt and clay deposit on the agricultural lands and crop residue. These coatings include soil organic carbon (C), microbes, and pathogens. After the coating dried, they were incorporated into the topsoil layer of the alluvial soils using tillage equipment. The mixing in of sediment into the topsoil seemed to have resulted in little significant loss of soil productivity (Olson and Morton 2012b; 2013b).

\section{IMPACT OF THE 2011 FLOODING ON ANGELO TOWHEAD CONSERVATION AREA}

Angelo Towhead (figure 1) is an island in the middle of the Upper Mississippi River just north of the confluence. The 200 ha (500 ac) of soils on the Angelo Towhead are mapped as alluvial lands (Parks and 


\section{Figure 5}

The $19.4 \mathrm{~m}$ Ohio River floodwall in August of 2012 when the Ohio River was at $\mathbf{3 . 6}$ $\mathrm{m}$ or $15.1 \mathrm{~m}$ lower than it was on May 2, 2011.

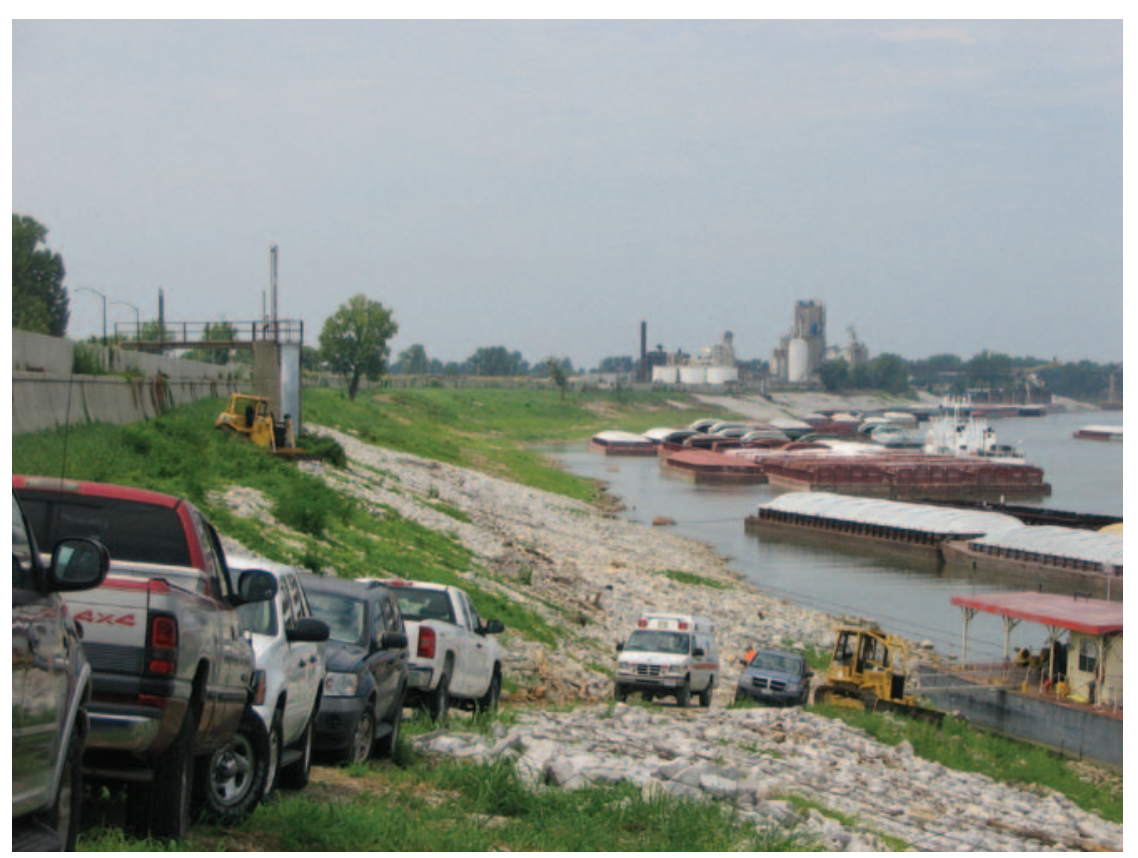

\section{Figure 6}

Soybean field located between the Upper Mississippi River and the Cairo, Illinois, levee. The US 60 bridge over the Mississippi River connects Illinois and Missouri.

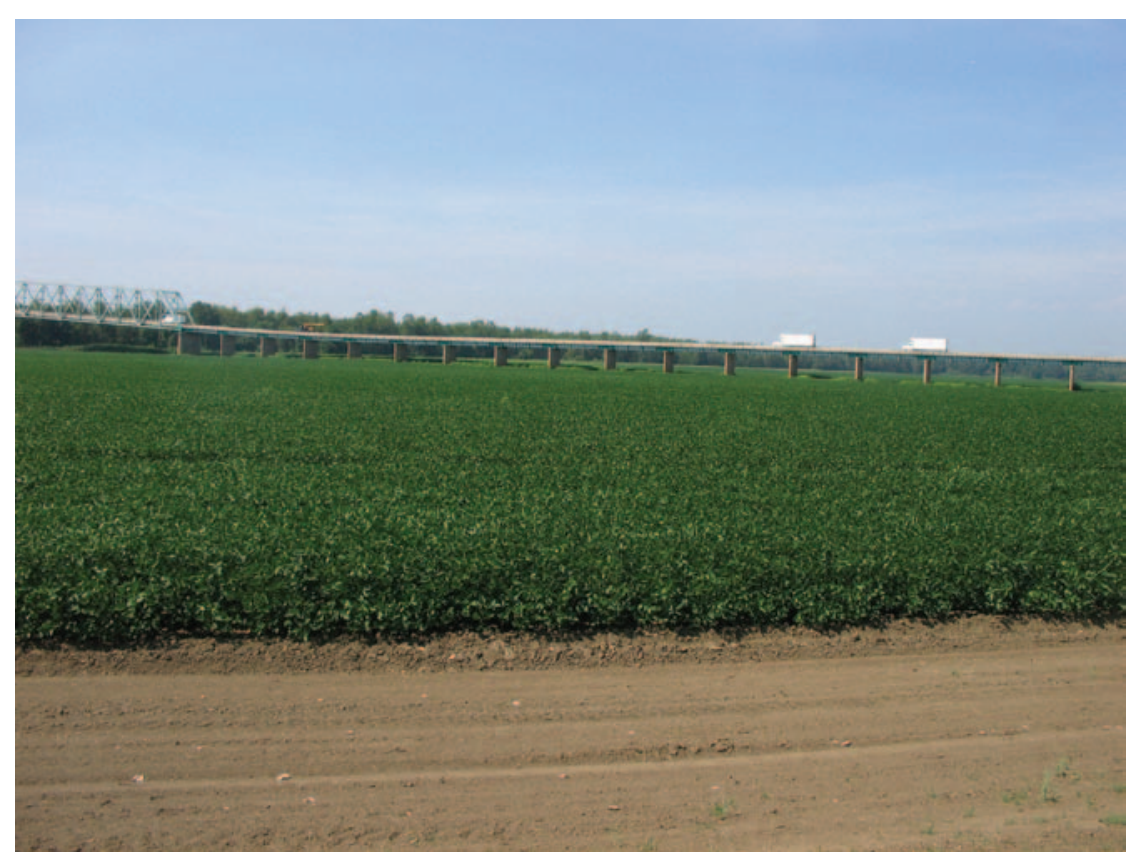

Fehrenbacher 1968). Alluvial land consists of recently deposited sediment that varies widely in texture (from clay to sand), and layers are commonly stratified. These soils were mapped between 1957 and 1963, and recent deposition and erosion have not been surveyed. The natural forest vegetation ranges from recent growth of willows (Salix nigra) and other plants to stands of cottonwood (Populus deltoids), sycamore (Platanus occidentalis), and sweet gum (Liguidambar styraciflua). Angelo Towhead is at an elevation of 93.9 to 94.5 $\mathrm{m}$ (310 to $315 \mathrm{ft}$ ). At flood stage on the

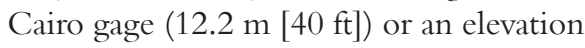
of $93.9 \mathrm{~m}(310 \mathrm{ft})$, the island vegetation is at water level with higher portions of

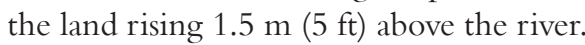
On May 2, 2011, on the day of the record peak on the Cairo gage, Angelo Towhead was 5.2 to $6.7 \mathrm{~m}$ (17 to $22 \mathrm{ft})$ underwater with only the tree tops still showing above the Mississippi River floodwaters. During the drought of 2012, the island land mass was exposed 8.5 to $10 \mathrm{~m}$ (28 to $33 \mathrm{ft}$ ) above the level of the river and had to be avoided by the river traffic. This 16.7 $\mathrm{m}(55 \mathrm{ft})$ change in the surface elevation of the Mississippi River occurred within a 15-month period.

The island, like other bottomlands between the river and uplands, consists of riparian forests - transition ecosystems which have fertile, fine textured clay or loam soils that are enriched by nutrients and sediments deposited during floods (Anderson and Samargo 2007). The species of the alluvial river bottomland are well adapted to periodic flood cycles, which can last several days to a month or more (Anderson and Samargo 2007). The impact of the 2011 flood duration ( 2 to 4 weeks) on these wetlands, wildlife habitat, and woodlands as well as reproduction timing on nesting and fledging of bird populations on Angelo Towhead and adjacent alluvial land along the Mississippi River have not been assessed. However this ecosystem is well suited to periodic inundation from heavy rainfall and river flooding. The Illinois bottomlands provide additional water storage capacity during flooding, and the wet soils help filter pollutants, recharge the water table, and capture sediment before it reaches 
the main flow of the Mississippi River (Anderson and Samargo 2007).

\section{CONCLUSIONS}

Flood waters from the Ohio River in April of 2011 were more than $6.2 \mathrm{~m}$ (21 $\mathrm{ft}$ ) above flood stage and $7.2 \mathrm{~km}$ (4.5 mi) wide as they approached the confluence. As a result there was tremendous pressure on and under the Ohio River floodwall and the Upper Mississippi River levee in the Cairo area. Sand boils, a mega boil, sinkholes, and seepage occurred, and the entire floodwall and levee system was very close to failure. Failure would have resulted in $6.7 \mathrm{~m}(22 \mathrm{ft})$ of water covering the city of Cairo at a time when 2,900 people living in Cairo had yet to be evacuated. When the record flood peak reached $18.7 \mathrm{~m}$ (61.7 $\mathrm{ft})$, the USACE engineers blasted open the Birds Point fuse plug levee taking pressure off the Cairo system. As a result no flood damage of building structures occurred in Cairo since the floodwall and levee system held. Had it failed, all 400 homes and commercial buildings would have been severely damaged by $6.7 \mathrm{~m}(22 \mathrm{ft})$ of floodwater (Olson and Morton 2012a).

Two years later, the Cairo levee system had been strengthened with considerable investment in repairing infrastructure damaged by sand boils, and its integrity has been restored with the addition of relief wells along the Ohio River side of the Cairo levee. Sinkholes in the city of Cairo roads were repaired by fall of 2013. The US-60 bridge over the Mississippi River (figure 6), which connects Cairo, Illinois, and Birds Point, Missouri, was reopened in 2012 but through 2014 continued to be periodically closed for repairs. When the bridge was closed, the local Missouri and Illinois residents had to travel an additional 27 km (17 miles) between Birds Point, Missouri, and Cairo, Illinois, and interstate commerce was substantively affected.

The USACE spent US\$26 million to restore the Cairo area floodwall, levees, streets, and shipping channel. Levee strengthening and repairs included the creation of 31 relief wells in Cairo along the Ohio River floodwall.

There was no significant soybean damage or yield reductions in the agricultural lands since the flooding occurred during the non-growing season. Had winter wheat
(Triticum aestivum L.) been planted in fall of 2010, the crop would have drowned. Illinois farmers are aware of the flooding potential, especially in the winter and early spring, so they usually do not plant winter wheat in flood prone areas, and consequently there was no crop loss. In anticipation of future flooding events, the USACE repaired the three sections of the New Madrid frontline levee that were deliberately breached (Olson and Morton 2013a; Morton and Olson 2013) and repaired the stream bank base of the floodwall in Cairo to help prevent future sand boils, mega boils, sinkholes, and piping from both the Ohio and Mississippi rivers.

\section{ACKNOWLEDGEMENTS}

Partial funding for this research was provided by the USDA National Institute of Food and Agriculture Integrated Water Program agreement 2008-51130-19526, Heartland Regional Water Coordination Initiative, and the Iowa Agriculture and Home Economics Experiment Station, College of Agriculture and Life Sciences at Iowa State University. Additional funding support comes from Regional Research Project No. 15-372 and in cooperation with North-Central Regional Project No. NCERA-3 Soil Survey. This research is published with funding support from the Director of the Illinois Office of Research, College of Agriculture, Consumer, and Environmental Sciences, University of Illinois, Urbana, Illinois.

\section{REFERENCES}

Anderson, J., and E. Samargo. 2007. Bottomland Hardwoods. Morgantown, WV: West Virginia University, Division of Forestry and Natural Resources. http://forestandrange.org/new_wetlands/index.htm.

Barry, J. M. 1997. Rising Tide:The Great Mississippi Flood of 1927 and How It Changed America. New York: Simon \& Schuster.

Camillo, C.A. 2012. Divine Providence: The 2011 Flood in Mississippi River and Tributaries Project. Vicksburg, Mississippi: Mississippi River Commission.

Koenig, R. 2012. Corps balancing levee repairs on Missouri, Illinois sides of Mississippi. St. Louis Beacon. July 30, 2012.

Lansden, J.M. (1910) 2009. A History of the City of Cairo, Illinois. Carbondale, IL: Southern Illinois University Press.

Morton, L.W., and K.R. Olson. 2013. Birds Point-New Madrid Floodway: Redesign, recon- struction and restoration. Journal of Soil Water Conservation 69(2):35A-40A, doi:10.2489/ jswc.68.2.35A.

NOAA (National Oceanic Atmosphere Administration). 2012. Historic crests. Cairo, IL: National Weather Service, Advanced Hydrologic Prediction Service.

Olson, K.R., and L W. Morton. 2012a. The effects of 2011 Ohio and Mississippi River valley flooding on Cairo, Illinois, area. Journal of Soil Water Conservation 67(2):42A-46A, doi:10.2489/ jswc.67.2.42A.

Olson, K.R., and L W. Morton. 2012b. The impacts of 2011 induced levee breaches on agricultural lands of Mississippi River Valley. Journal of Soil Water Conservation 67(1):5A-10A, doi:10.2489/ jswc.67.1.5A.

Olson, K.R., and L W. Morton. 2013a. Restoration of 2011 flood damaged Birds Point-New Madrid Floodway. Journal of Soil Water Conservation 68(1):13A-18A, doi:10.2489/jswc.68.1.13A.

Olson, K.R., and L.W Morton. 2013b. Soil and crop damages as a result of levee breaches on Ohio and Mississippi rivers. Journal of Earth Science and Engineering 3:139-158.

Olson, K.R., and L W. Morton. 2014. Ohio River flooding of the Cache River Valley in Southern Illinois. Journal of Soil Water Conservation 69(1):5A-10A

Parks, W. D., and J. B. Fehrenbacher. 1968. Soil Survey of Pulaski and Alexander counties, Illinois. Washington, DC: USDA Natural Resource Conservation Service.

Veesaert, C.J. 1990. Inspection of Embankment Dams. Session X in Embankment Dams. Bureau of Reclamation. http://www.michigan.gov/ documents/deq/deq-p2ca-embankmentdaminspection_281088_7.pdf. 